\title{
RETINOBLASTOMA OCCURRENCE OF THE CONDITION IN NORTHERN IRELAND, 1938-1956
}

\author{
BY \\ A. C. STEVENSON AND V. A. F. MARTIN \\ Department of Social and Preventive Medicine, Queen's University, Belfast, \\ and Benn Hospital, Belfast.
}

The current genetical hypothesis regarding retinoblastoma is that it is determined by a single dominant gene which is not always manifested, so that the condition frequently misses a generation or first appears in a sibship with several affected members. The condition is rare and consanguinity is seldom reported either in the unaffected parents of "sporadic" cases or in sibships having more than one affected member. The irregular dominant gene hypothesis appears adequate without having to postulate also a recessive gene or other mechanism.

The condition arises in the first few years of life and determines a high mortality even if it is modified by prompt enucleation of affected eyes. Further, survivors are either totally blind or have only one eye, and for social reasons they probably have a low fertility. As would be expected, therefore, a high proportion of all cases seen are sporadic, that is single cases and the first known cases in the family. This paper is concerned with the known cases which have occurred in Northern Ireland from January 1, 1938, to December 31, 1956.

\section{Material AND Methods}

It was decided to attempt to make a "complete ascertainment" of cases which had occurred in Northern Ireland since January 1, 1938. The arbitrary starting point was chosen as it was considered that families which had had affected members arising before that time would be increasingly difficult to trace. All pathological reports on enucleated eyes were searched for in the hospitals where such operations are performed in Northern Ireland. Ophthalmologists were most helpful in letting us have information about their hospital and private cases, the records of the Ulster schools for the deaf and blind and partially sighted children were consulted, and School and Child Welfare Medical Officers notified known or suspicious cases. Finally, by courtesy of the Registrar-General for Northern Ireland, it was possible to attempt to trace deaths certified as due to retinoblastoma or glioma of the retina.

Table I suggests that it is almost certain that we have failed to find a considerable number of cases which occurred in the war and immediate post-war years. The only other explanation of the time distributions of the births and diagnoses would be that the condition has become commoner since the war, and that seems unlikely. There is a gap in biopsy and enucleation reports in ophthalmic hospitals and departments during the war and immediate post-war years. For some unexplained reason, the death certificates of subjects often fail to mention retinoblastoma as a cause of death so that records could not be checked from this source. The low incidence in the last two years (1955-56) is presumably attributable to the fact that in many cases the condition is not diagnosed until some time after birth.

TABLE I

YEARS OF BIRTH AND OF DIAGNOSIS OF 23 "SPORADIC" CASES OF RETINOBLASTOMA

\begin{tabular}{|c|c|c|c|}
\hline Year & $\begin{array}{l}\text { Cases } \\
\text { Born }\end{array}$ & $\begin{array}{c}\text { Cases } \\
\text { Diagnosed }\end{array}$ & $\begin{array}{l}\text { Live Births } \\
\text { Northern Ireland }\end{array}$ \\
\hline $\begin{array}{l}1935 \\
1936 \\
1937 \\
1938 \\
1939 \\
1940 \\
1941 \\
1942 \\
1943 \\
1944 \\
1945 \\
1946 \\
1947 \\
1948 \\
1949 \\
1950 \\
1951 \\
1952 \\
1953 \\
1954 \\
1955 \\
1956\end{array}$ & $\begin{array}{l}1 \\
3 \\
- \\
1 \\
1 \\
= \\
= \\
2 \\
1 \\
2 \\
3 \\
2 \\
3 \\
1\end{array}$ & $\begin{array}{l}- \\
\overline{1} \\
1 \\
\frac{1}{1} \\
\frac{1}{-} \\
\frac{2}{2} \\
1 \\
4 \\
3 \\
3 \\
3\end{array}$ & $\begin{array}{l}24,742 \\
25,909 \\
25,412 \\
25,742 \\
25,240 \\
25,363 \\
26,887 \\
29,645 \\
31,521 \\
30,900 \\
29,007 \\
30,134 \\
31,254 \\
29,532 \\
29,106 \\
28,794 \\
28,477 \\
28,760 \\
28,984 \\
28,803 \\
28,965 \\
29,400 \text { (estimate) }\end{array}$ \\
\hline Total & 23 & 23 & 622,577 \\
\hline
\end{tabular}


DATA RELATING TO SUBJECTS

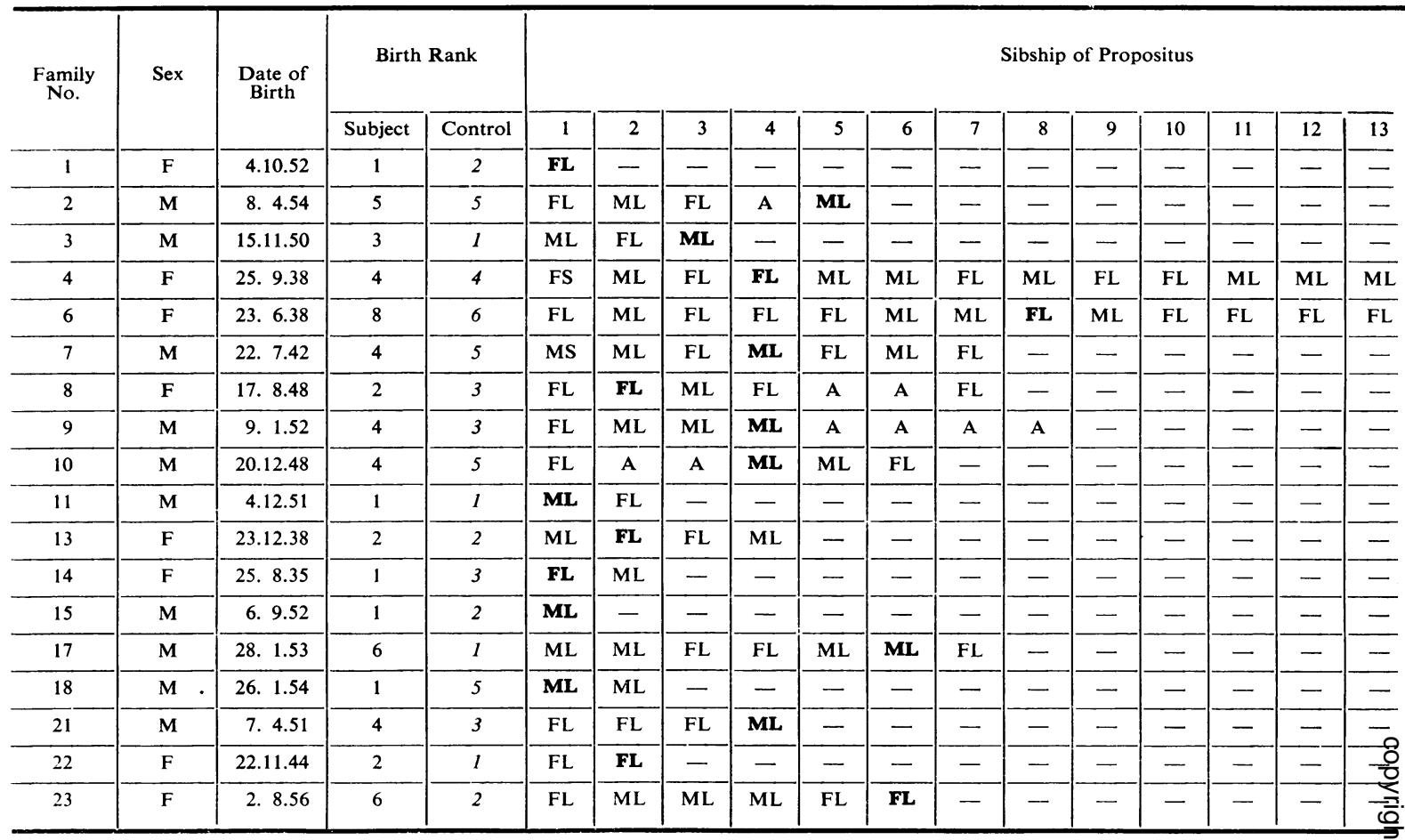

1. $\mathbf{M}=$ Male; $\mathbf{F}=$ Female; $\mathbf{L}=$ Livebirth $\mathbf{S}=$ Stillbirth; $\mathbf{A}=$ Abortion.

2. The affected propositi are printed in bold type, e.g. ML

All the 23 families ascertained were traced and each was visited and a full family history taken. None of the parents knew of being related to each other in any way. There was no history of the condition in any family, so that all the cases must be considered "sporadic". A biopsy report confirming the diagnosis was available for each case.

Table II sets out the basic data necessary for consideration of the genetical aspects of the condition in subjects in whom the condition was (at least up to the time of writing) unilateral.

Table III (overleaf) sets out the comparable data in respect of families in which the subject had both eyes affected.

\section{RESULTS}

Survival.-The average age at which the condition was diagnosed for the first eye in the eighteen unilateral cases was 1 year 8 months (range 1 to 54 months). The average age at diagnosis of the first affected eye in the five bilateral cases was 2 years (range 15 months to 3 years).

Of the eighteen unilateral cases, seven had survived more than 5 years from diagnosis, and three had died (at 13, 12, and 8 months after diagnosis). Two of the bilateral cases had died (at 54 and 19 months after diagnosis of the first eye) and three are alive (at 59, 49, and 1 month after diagnosis of the first eye).

FREQUENCY.-Over the whole period there were 23 cases in 622,577 live births or approximately 37 per million live births (Table I). For reasons stated above, this must be regarded as a minimum estimate and, if only the latter half of the period, namely July 1,1947 , to December 31,1956 , is considered, the figures are 17 in 292,075 live births or approximately 58 per million live births. To avoid the complications of the overlapping of years of birth and years of diagnosis, it seems better to take the frequency as cases diagnosed per births occurring in these years. The difference in the frequency from that calculated by using cases born each year as the denominator is very small.

Unilateral and Bilateral Cases.-The pattern of occurrence of unilateral and bilateral cases of retinoblastoma is of particular interest and relevance 


\begin{tabular}{|c|c|c|c|c|c|c|c|c|c|c|c|}
\hline \multirow[b]{3}{*}{14} & \multirow[b]{3}{*}{15} & \multirow[b]{3}{*}{16} & \multirow[b]{3}{*}{17} & \multicolumn{4}{|c|}{$\begin{array}{c}\text { Parental Age (yrs) } \\
\text { at Birth }\end{array}$} & \multirow{3}{*}{ Side } & \multirow{3}{*}{$\begin{array}{c}\text { Age at } \\
\text { Diagnosis } \\
\text { (mths) }\end{array}$} & \multirow{3}{*}{$\begin{array}{c}\text { Age at } \\
\text { Enucleation } \\
\text { (mths) }\end{array}$} & \multirow{3}{*}{ Period of Survival after Diagnosis } \\
\hline & & & & \multicolumn{2}{|c|}{ Father } & \multicolumn{2}{|c|}{ Mother } & & & & \\
\hline & & & & Subject & Control & $\overline{\text { Subject }}$ & Control & & & & \\
\hline - & - & - & - & 33 & 33 & 35 & 22 & $\mathbf{R}$ & 18 & 18 & Alive 2 yrs later (aged $3 \frac{1}{2}$ yrs) \\
\hline$\overline{-}$ & - & - & - & 31 & 32 & 29 & 34 & $\mathbf{R}$ & 20 & 21 & Alive $8 \mathrm{mths}$ later (aged $2 \mathrm{yrs} 4 \mathrm{mths}$ ) \\
\hline$\overline{-}$ & - & - & - & 30 & 21 & 40 & 22 & $\mathbf{R}$ & 24 & 30 & Died 1 yr later (aged 3 yrs) \\
\hline FL & $\mathbf{A}$ & $\mathbf{A}$ & - & 26 & 37 & 24 & 35 & $\mathbf{R}$ & 23 & 24 & Alive 16 yrs later (aged 18 yrs) \\
\hline$\overline{-}$ & - & - & - & 48 & 42 & 35 & 39 & $\mathbf{L}$ & 36 & 37 & Alive 15 yrs later (aged 18 yrs) \\
\hline$\overline{-}$ & - & - & - & 30 & 42 & 23 & 37 & $\mathbf{L}$ & 7 & 18 & Alive 13 yrs $5 \mathrm{mths}$ later (aged $14 \mathrm{yrs}$ ) \\
\hline$\overline{-}$ & - & - & - & 30 & 29 & 34 & 28 & $\mathbf{L}$ & 9 & 14 & Alive 7 yrs $3 \mathrm{mths}$ later (aged 8 yrs) \\
\hline$\overline{-}$ & - & 一 & - & 39 & 37 & 33 & 37 & $\mathbf{R}$ & 32 & 36 & Alive 1 yr $10 \mathrm{mths}$ later (aged 4 yrs $4 \mathrm{mths}$ ) \\
\hline$\overline{-}$ & - & - & - & 37 & 34 & 36 & 26 & $\mathbf{L}$ & 12 & 18 & Died 1 yr later (aged 2 yrs) \\
\hline$\overline{-}$ & - & - & - & 34 & 22 & 36 & 21 & $\mathbf{L}$ & 6 & 30 & Alive 2 yrs $4 \mathrm{mths}$ later (aged 2 yrs $10 \mathrm{mths}$ ) \\
\hline - & - & - & - & 27 & 22 & 26 & 20 & $\mathbf{L}$ & 24 & 32 & Alive 15 yrs later (aged 17 yrs) \\
\hline- & - & - & - & $? 47$ & 46 & $? 45$ & 34 & $\mathbf{R}$ & 36 & 38 & Alive 17 yrs later (aged 20 yrs) \\
\hline$\overline{-}$ & - & - & - & 26 & 28 & 24 & 24 & $\mathbf{L}$ & 9 & 24 & Alive 3 yrs 4 mths later (aged 4 yrs) \\
\hline 一 & 一 & - & - & 38 & 31 & 34 & 24 & $\mathbf{L}$ & 24 & 28 & Died $8 \mathrm{mths}$ later (aged 2 yrs $8 \mathrm{mths}$ ) \\
\hline- & - & - & - & 24 & 33 & 22 & 29 & $\mathbf{R}$ & 3 & 7 & Alive 2 yrs $4 \mathrm{mths}$ later (aged 2 yrs $7 \mathrm{mths}$ ) \\
\hline- & - & - & - & 38 & 34 & 36 & 34 & L & 54 & 57 & Alive $10 \mathrm{mths}$ later (aged 5 yrs $4 \mathrm{mths}$ ) \\
\hline- & - & - & 一 & 30 & 49 & 23 & 28 & $\mathbf{L}$ & 23 & 27 & Alive 5 yrs later (aged 7 yrs) \\
\hline - & - & - & - & 37 & 24 & 29 & 21 & $\mathbf{R}$ & 1 & 3 & Alive $4 \mathrm{mths}$ later (aged $5 \mathrm{mths}$ ) \\
\hline
\end{tabular}

3. The figures in italics under Birth Rank and Parental Age apply to the control series.

4. $R$ and $L$ in column headed Side means right or left eye.

to the genetical hypothesis. It has long been noted that a high proportion of sporadic cases are unilateral (as in this series, where eighteen of 23 sporadic cases are unilateral), whereas in cases with affected relatives a much smaller proportion, probably less than half, are unilateral (Griffith and Sorsby, 1944; Franceschetti and Bischler, 1946; Falls and Neel, 1951). This observation has been the starting point for the suggestion that some unilateral cases are not hereditarily determined but represent somatic mutations (Falls and Neel, 1951; Vogel, 1954).

It seems worth while therefore to examine the pattern of occurrence of unilateral and bilateral cases in a little more detail and then to discuss the arguments for the occurrence of somatic mutations.

(a) Over-estimation of True Proportion of Unilateral Cases in Any Series.-In many cases which subsequently prove to be bilateral, the affection is noted in one eye before it can be detected in the other. The time interval between the detection of the condition in the first and second eyes may only be a few weeks. In the present series the mean interval in the five cases was 11 months (range 0 to 18 months.) It is seldom more than 18 months, and a second eye seldom or never becomes affected more than 5 years after the first. Any series of cases, therefore, may include children who died from the effects of the first eye, and it is a matter of surmise whether, if the child had survived, the second eye would have become affected. Most series also include children whose first eye became affected less than 5 years before the cases were reported, and again it is impossible to tell the fate of the second eye. Presumably some of each of the above groups are potentially bilateral.

There is also good evidence (Duke-Elder, 1940; Hine, 1937; Griffith and Sorsby, 1944) that tumours may appear and retrogress, leaving little functional disability or signs in the eye. It seems logical to suppose that the smallest manifestations of tumours may be missed or be indeed indetectable. They may even be only potential tumours, in that if involvement of the second eye does not occur within a few years some developmental-time association may determine that it never occurs. Stated in genetical terms, it may be said that, if there were separate genotypes, then bilateral genotype would be the 
TABLE III

DATA RELATING TO SUBJECTS WITH BOTH EYES AFFECTED

\begin{tabular}{|c|c|c|c|c|c|c|c|c|c|c|c|c|c|c|c|c|c|c|}
\hline \multirow{3}{*}{$\begin{array}{l}\text { Fam- } \\
\text { ily } \\
\text { No. }\end{array}$} & \multirow{3}{*}{ Sex } & \multirow{3}{*}{$\begin{array}{l}\text { Date } \\
\text { of } \\
\text { Birth }\end{array}$} & \multirow{2}{*}{\multicolumn{2}{|c|}{$\begin{array}{l}\text { Birth } \\
\text { Rank }\end{array}$}} & \multirow{2}{*}{\multicolumn{5}{|c|}{ Sibship of Propositus }} & \multicolumn{4}{|c|}{$\begin{array}{c}\text { Parental Age (yrs) } \\
\text { at Birth }\end{array}$} & \multirow{3}{*}{\begin{tabular}{|c|} 
Age \\
at \\
Diag- \\
nosis \\
of \\
First \\
Eye \\
(mths)
\end{tabular}} & \multirow{3}{*}{$\begin{array}{c}\text { Age } \\
\text { at } \\
\text { Diag- } \\
\text { nosis } \\
\text { of } \\
\text { Sec- } \\
\text { ond } \\
\text { Eye } \\
\text { (mths) }\end{array}$} & \multirow{3}{*}{ Treatment } & \multirow{3}{*}{$\begin{array}{c}\text { Age } \\
\text { at } \\
\text { Treat- } \\
\text { ment } \\
\text { (mths) }\end{array}$} & \multirow{3}{*}{$\begin{array}{l}\text { Period of } \\
\text { Survival } \\
\text { after First } \\
\text { Diagnosis }\end{array}$} \\
\hline & & & & & & & & & & \multicolumn{2}{|c|}{ Father } & \multicolumn{2}{|c|}{ Mother } & & & & & \\
\hline & & & $\begin{array}{c}\text { Sub- } \\
\text { ject }\end{array}$ & $\begin{array}{c}\text { Con- } \\
\text { trol }\end{array}$ & 1 & 2 & 3 & 4 & 5 & $\begin{array}{c}\text { Sub- } \\
\text { ject }\end{array}$ & $\begin{array}{c}\text { Con- } \\
\text { trol }\end{array}$ & $\begin{array}{c}\text { Sub- } \\
\text { ject }\end{array}$ & $\begin{array}{c}\text { Con - } \\
\text { trol }\end{array}$ & & & & & \\
\hline 5 & $\mathbf{F}$ & 7. 9.41 & 2 & $I$ & ML & FL & FL & ML & 一 & 26 & 25 & 23 & 23 & 36 & 48 & $\begin{array}{l}\text { Right eye removed. } \\
\text { Left eye treated } \\
\text { with radium only. }\end{array}$ & 36 & $\begin{array}{l}\text { Died } 54 \\
\text { mths later } \\
\text { (aged } 7 \frac{1}{2} \\
\text { yrs) }\end{array}$ \\
\hline 12 & $\mathbf{F}$ & 2.11 .53 & 1 & 3 & $\mathbf{F L}$ & ML & 一 & 一 & - & 39 & 32 & 32 & 26 & 15 & 26 & $\begin{array}{l}\text { Left eye removed } \\
\text { after radium treat- } \\
\text { ment: parents pre- } \\
\text { viously refused enu- } \\
\text { cleation. } \\
\text { About same time } \\
\text { right eye seen to be } \\
\text { affected. }\end{array}$ & 29 & $\begin{array}{c}\text { Died } 19 \\
\text { mths later } \\
\text { (aged } \\
2 \text { yrs } \\
10 \text { mths) }\end{array}$ \\
\hline 16 & $\mathbf{M}$ & 6. 5.51 & 2 & 2 & FL & ML & - & - & - & 30 & 23 & 24 & 25 & 18 & 28 & $\begin{array}{l}\text { Left eye enucleated. } \\
\text { Right eye treated } \\
\text { with radium. }\end{array}$ & $\begin{array}{l}19 \\
21\end{array}$ & $\begin{array}{l}\text { Alive } 59 \\
\text { mths later } \\
\text { (aged } 6 \text { yrs } \\
5 \text { mths) }\end{array}$ \\
\hline 19 & $\mathbf{M}$ & 15. 3.50 & 5 & 1 & ML & ML & ML & ML & ML & 39 & 22 & 36 & 21 & 30 & 48 & $\begin{array}{l}\text { Left eye removed. } \\
\text { Right eye removed. }\end{array}$ & $\begin{array}{l}33 \\
53\end{array}$ & $\begin{array}{c}\text { Alive } 49 \\
\text { mths later } \\
\text { (aged } 6 \text { yrs } \\
7 \text { mths) }\end{array}$ \\
\hline 20 & $\mathbf{F}$ & 2.12 .54 & 5 & 1 & ML & FL & ML & ML & FL & 37 & 27 & 35 & 24 & 19 & 19 & $\begin{array}{l}\text { Left eye removed. } \\
\text { Right eye treated } \\
\text { with radon. }\end{array}$ & 19 & $\begin{array}{l}\text { Alive } 1 \\
\text { mth later } \\
\text { (aged 1 yr } \\
8 \text { mths) }\end{array}$ \\
\hline
\end{tabular}

under-estimated from the observed proportion of phenotypic expression in any series.

(b) Proportion with Unilateral Affection in Sporadic Cases and in Those with Affected Relatives.-The factors which determine over-estimation of the proportion of unilateral cases in any series apply both to sporadic cases and to those having affected relatives. However, on an average, about 75 per cent. of sporadic cases reported in the literature are unilateral, but only about 45 per cent. of the cases having affected relatives are unilateral. A slightly greater proportion of bilateral cases might be expected in the latter, as more subjects, notably those affected in previous generations and older sibs, would be observed for a longer period and would thus have a greater chance of becoming bilateral. The difference in proportion is, however, much too great to be explained on such a basis. Even taking only living sporadic cases observed for more than 5 years after diagnosis of the first eye, approximately 65 per cent. are still unilateral (Falls and Neel, 1951).

It is instructive to examine a little more closely an unselected series of pedigrees such as those reported from the literature by Griffith and Sorsby (1944). Of the pedigrees which they reproduce (pp. 288, 289 , and 290), a number have to be excluded because they contain some members of whom it is not known from the original accounts whether one or both eyes were affected. The unilateral and bilateral cases in their relationships in the remaining pedigrees are shown in Table IV (opposite).

It is clear that, if this series is representative, it is mainly unilateral cases and the appropriate genotypes having normal phenotypes who are usually the first affected in families. It is also clear that it is not uncommon for unilaterally affected persons to have bilaterally affected offspring (Griffith and Sorsby, p. 289), and for bilaterally affected parents to have unilaterally affected offspring (Fairclough, 1947; Falls and Neel, 1951; Weller, 1941).

(c) Suggestion that a Number of the Unilateral Cases represent the Expression of Somatic Mutations.-As mentioned above, Falls and Neel (1951) pointed out that the possibility of the occurrence of somatic mutation could not be excluded, and Vogel (1954) takes the suggestion further by attempting to produce evidence that, when unilateral sporadic cases marry, an undue proportion fail to produce affected subjects among their offspring. If such evidence could be produced, and if it could be shown that no such phenomenon occurred in the offspring of sporadic bilateral cases but that in the pooled 
TABLE IV

PEDIGREES IN THE LITERATURE

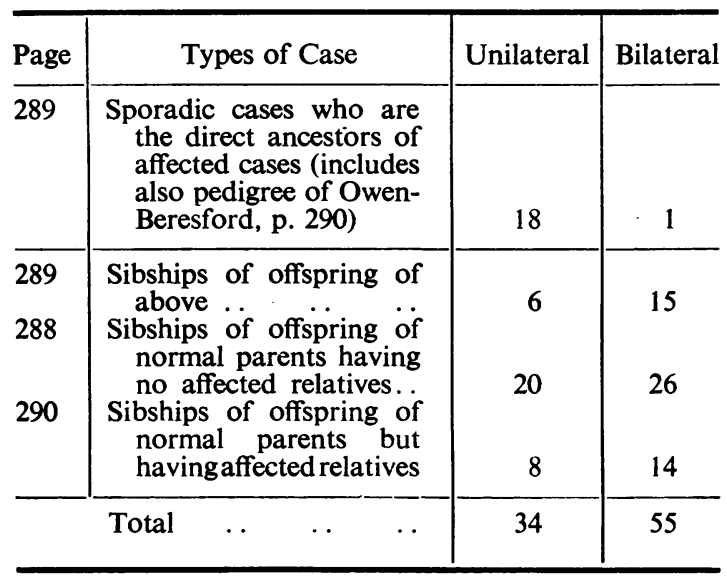

Those excluded are:-

p. 289, Van der Hoeve, Weller-Sleight, Maher-Pockley. Best, Milanowski, Odinzow, and Taylor;

p. 288, Emrooth, Fuchs, Nemoto, Boyd, Von Graefe, Wilson, Sichel, Calderini, Comas, Dabney, Marshall, Valenti, Flexner, and Wintersteiner;

p. 290, Hemmes, Von Graefe, Lukens, Feinstein, and Thompson and Knapp.

sibships of such offspring approximately half were affected, this would support a somatic mutation theory.

Owing to the rarity of the condition and the low fertility of affected subjects, it is most unlikely that evidence of this kind will ever come from complete ascertainment series reported by a single author. It is also unlikely that sporadic cases of retinoblastoma having normal or affected children are reported randomly by ophthalmologists. The former may well be considered as lacking in interest by non-geneticists.

Vogel gives a Table of nineteen fertile matings, reported by six authors, between unilateral sporadic cases and normal persons. These matings are, he says, the only ones in the literature at that time which were ascertained solely by an affected parent. Only three of 43 offspring were affected. He concludes that about 75 per cent. of unilateral sporadic cases of retinoblastoma represent somatic mutations. (Hence the mutation rate as calculated by him from his data is just over 4 per million, but if calculated on the same basis as that of other authors (Falls and Neel, 1951; Philip and Sorsby, 1944), the rate would be 17 per million). Vogel excludes all the families in the literature in which a unilateral sporadic case of retinoblastoma had affected offspring except those families which were apparently ascertained through an affected child, and he is right in his insistence that, if ascertainment were through an affected child, a thoroughly biased series of matings and offspring would be collected. What he overlooks, however, is that, in practice, it is almost impossible to ascertain a two-generation family only by those affected in the first generation. The families he quotes are therefore unlikely to be representative of all matings of sporadic unilateral cases, but probably represent a selected series, in that the majority could not have been ascertained through a second generation case.

It seems to us to be quite impossible to determine from any available data, this important point, namely:

What proportion of sporadic cases, unilateral and/ or bilateral, when they marry and have children, have affected children, making allowance for sibship size of offspring, and chance distribution of affected in sibships on the hypothesis of an expected 50 per cent. affected?

It is certain that many unilateral cases are of the same genotype as bilateral cases. The eighteen unilaterally affected parents in the pedigrees collected by Griffith and Sorsby (1944) had unilaterally and bilaterally affected offspring, and there are many pedigrees illustrating all relationships of unilateral and bilateral cases as sibs, as parent and child, and as child and parent.

(d) Possible Histological Differences.-The only positive evidence of a qualitative difference between unilateral and bilateral cases is that suggested by Cumings and Sorsby (1944). These writers examined carefully the tumours of eight sporadic unilateral cases, eight sporadic bilateral cases, and three bilateral cases with a positive family history. They concluded that, in the eight sporadic unilateral tumours, the condition originated in the outer nuclear layer of the retina. They could not find distinguishing points between the bilateral sporadic tumours and the hereditary bilateral tumours, but considered both to be distinguishable from the sporadic unilateral tumours in that they arose in the inner nuclear layers of the retina or from both layers. As far as the present writers can discover, these observations have not been repeated by other observers. The data given in the paper do not include an assurance that some of the unilateral cases did not subsequently become bilateral, and at least two of the cases had their enucleations within 2 years of the report being made, so that a second eye could subsequently have been affected. Further, from the evidence of many pedigrees, it seems unlikely that somatic mutation, even if it does occur, is very common-even sufficiently common for an unselected series of eight cases all to be of such 
origin. It would have been helpful if examinations could also have been made of the eyes of unilateral cases where the condition had definitely been transmitted or received, for as noted above there are many such cases. It may be noted also that Franceschetti and Bischler (1946) have reported retinoblastomas in a father and son which showed gross histological differences, certainly as great as the differences described by Cumings and Sorsby.

Mutation Rates.-Assuming all cases here reported to be recipients of a fresh dominant mutation at the same locus, the mutation rates estimated would be half of the figures for frequency as calculated, namely 18.5 per million, if the whole period 1938-56 is considered, and 29 per million for the second half of the period where the evidence is that the ascertainment was much better. The latter would seem to be the better estimate for Northern Ireland. This may be compared with estimations calculated in the same way by Philip and Sorsby (1944) of 17 per million, Falls and Neel (1951) of 23 per million, and Vogel (1954) of 17 per million.

Factors tending to make 29 per million an underestimate of the rate per locus would be failure of ascertainment of fresh cases and missing of retrogressed cases, but both would probably have small effects.

The estimate is too large if somatic mutations are included in the unilateral cases, or if genes at other loci can cause the condition.

"ANTICIPATION".--It seems likely that more unilateral than bilateral cases grow up, marry, and have children. The unilateral cases, as has already been demonstrated, preponderate in all sporadic series published. It is reasonable to assume therefore that a person of the appropriate genotype is more likely to transmit the condition if normal phenotypically, than if unilaterally affected (having survived childhood and being socially handicapped by the loss of one eye only), or than if bilaterally affected (the hazard of non-survival and the social handicap to marriage both being greater).

If bilateral cases are regarded as more "severe" than unilateral cases, then it follows that in families of two generations an undue proportion of cases will be more "severe" in the second than in the first generation and so "anticipation" is seen.

The preponderance of unilaterally affected in the sporadic cases still remains without any satisfactory explanation.

Parental Characteristics.-As no figures for parental ages were available in Northern Ireland, it was necessary to assemble a control series matching each subject for sex and year of birth. This was done by collecting the appropriate data in respect of a series of control subjects so selected attending the casualty out-patient departments of the Belfast teaching hospitals. The relevant data concerning parental age at the time of birth in the subjects and controls derived from Tables II and III are set out in Table $\mathrm{V}$. The numbers are small, and although there is a technically significant difference $(P<0.05)$ between the mean paternal ages of the bilateral cases and the control subjects, it would clearly be unwise to base any conclusions upon it. The data are in very marked contrast to those recently published from this department on achondroplasia (Stevenson, 1957) in which the age effect seemed to be most marked in the fathers of living achondroplastic subjects.

TABLE V

PARENTAL AGES AT BIRTH OF SUBJECTS WITH RETINOBLASTOMA

\begin{tabular}{|c|c|c|c|c|c|c|}
\hline & & No. & Pater & $\begin{array}{l}\text { nal Age } \\
\text { yrs) }\end{array}$ & Mate & $\begin{array}{l}\text { nnal Age } \\
\text { yrs) }\end{array}$ \\
\hline & & Cases & & Standard & & Standard \\
\hline & Subjects & 18 & $33 \cdot 61$ & $6 \cdot 81$ & $31 \cdot 33$ & $6 \cdot 62$ \\
\hline Unilateral & Controls & 18 & $33 \cdot 11$ & $8 \cdot 17$ & $28 \cdot 61$ & $6 \cdot 44$ \\
\hline & Subjects & 5 & $34 \cdot 20$ & $5 \cdot 89$ & $30 \cdot 00$ & $6 \cdot 12$ \\
\hline Bllateral & Controls & 5 & $25 \cdot 80$ & 3.96 & $23 \cdot 80$ & 1.92 \\
\hline
\end{tabular}

No parents had had any therapeutic $x$-ray or radium exposure or any fluoroscopic examinations.

As the information is available, it seems worth recording the number of radiographic examinations of the parents, although dosage from such sources is extremely small and any effects would not be detectable.

The mothers in Families 1, 11, 12 and 22 had abdominal radiography to establish the lie of the child in the 9th, 9th, 6th, and 8th months respectively of the appropriate pregnancies.

Only in four families was there a positive history of diagnostic radiography before the birth of the affected child. The details are set out in Table VI (opposite).

\section{SUMMARY}

In 23 subjects a diagnosis of retinoblastoma has been made in Northern Ireland in the period 1938 to 1956 inclusive. Reasons are given which suggest strongly that ascertainment is incomplete over the earlier part of the period, and it is concluded that the 
TABLE VI

DIAGNOSTIC RADIOGRAPHS OF PARENTS OF SUBJECTS BEFORE CONCEPTION OF THE CHILD

\begin{tabular}{c|c|c|c|c}
\hline \multirow{2}{*}{ Family No. } & \multicolumn{2}{|c|}{ Father } & \multicolumn{2}{|c}{ Mother } \\
\cline { 2 - 5 } & Site & \multicolumn{1}{|c}{ Date } & Site & \multicolumn{2}{c}{ Date } \\
\hline 11 & $\begin{array}{c}\text { Chest } \\
\text { Ankle } \\
\text { Hand }\end{array}$ & $\begin{array}{l}1938,1941,1950 \\
1950\end{array}$ & Chest & 1942 \\
\hline 15 & - & - & & \\
\hline 16 & - & - & $\begin{array}{l}\text { "Several chest } x \text {-rays follow- } \\
\text { ing pleurisy, 1948". cannot } \\
\text { (Hospital records cannon } \\
\text { be traced). }\end{array}$ \\
\hline 23 & Chest & 1953,1954 & Chest & 1944 \\
\hline
\end{tabular}

frequency in births over the latter half of the period is a reasonable estimate of the prevailing rate.

All the cases were sporadic, none having any known affected relatives. Eighteen are alive and five are dead. Eighteen subjects had only one eye affected (including three with only one eye affected at the time of death). Five subjects (two dead) had both eyes affected.

A direct estimate of the mutation rate calculated over the latter half of the period is 29 per million.

A study of the literature reveals that unilateral affection is more commonly observed in sporadic subjects than in those having affected relatives. It is difficult to explain all the excess of unilateral cases in sporadic subjects. If somatic mutation does occur and does account for some unilateral cases, the evidence from the literature suggests that it must be a rare phenomenon and one which does not contribute materially to the frequency of unilateral affection in sporadic cases.

The expenses of this investigation have been met by a grant to the Department of Social and Preventive Medicine from The Nuffield Foundation.

We have to acknowledge the able assistance of Dr. M. A. Lynas and Mrs. M. Y. Dudgeon in searching records and in visiting families. We are indebted to the Ophthalmologists on the staff of the Benn Hospital, Belfast Ophthalmic Hospital, and Royal Belfast Hospital for Sick Children for permitting us to search their records and for letting us know of private cases. We are also indebted to Mr. L. C. Mulligan, the Registrar-General for Northern Ireland, and to Mr. F. G. W. Denmark of the Ulster Schools for the Deaf and Blind for giving us access to records. Finally, we have to thank Miss P. Stewart and Miss D. Wood for help in preparing the manuscript.

\section{REFERENCES}

Cumings, J. N., and Sorsby, A. (1944). Brit. J. Ophthal., 28, 533. Duke-Elder, S. (1940). "Text-book of Ophthalmology", vol. 3. Kimpton, London,

Fairclough, W. A. (1947). Trans. ophthal. Soc. N.Z., p. 35.

Falls, H. F., and Neel, J. V. (1951). A.M.A. Arch. Ophthal., 46, 367. Franceschetti, A., and Bischler, V. (1946). Arch. Klaus-Stift, VererbForsch., 21, 322 .

Griffith, A. D., and Sorsby, A. (1944). Brit. J. Ophthal., 28, 279.

Hine, M. (1937). Trans. ophthal. Soc., U.K., 57, 173.

Philip, U., and Sorsby, A. (1944). Unpublished address-quoted by Falls and Neel (1951), based on Griffith and Sorsby (1944).

Vogel, F. (1954). Z. menschl. Vererb. u. Konstitlehre, 32, 308.

Weller, C. V. (1941). Cancer Res., 1, 517.

Stevenson, A. C. (1957). Amer. J. hum. Genet. (In Press). 